\title{
THE INTERNATIONAL PERSPECTIVE OF SOCIAL RIGHTS AS SOMETHING WE NEED TO BE MORE AWARE ABOUT
}

\section{Barbara Grandi}

Lawyer by the Bar of Livorno, Italy

E-mail: bg.grandi@gmail.com

Cite this article:

Barbara Grandi (2021), The International Perspective of Social Rights as Something we Need to be More Aware About. African Journal of Social Sciences and Humanities Research 4(4), 82106. DOI: 10.52589/AJSSHR9BYUDZYL.

\section{Manuscript History}

Received: 8 Oct 2021

Accepted: 1 Nov 2021

Published: 14 Nov 2021

Copyright $\odot 2020$ The Author(s). This is an Open Access article distributed under the terms of Creative Commons AttributionNonCommercial-NoDerivatives 4.0 International (CC BY-NC-ND

4.0 ), which permits anyone to share, use, reproduce and redistribute in any medium, provided the original author and source are credited.
ABSTRACT: Although the social security legal perspective is usually associated within a national legal frame, international developing relations are giving increasingly the opportunity to consider social security as something not necessarily granted within the State. This is rising the matter of labor as a direct source of social security as well as the need to mind social legislation philosophically before then defining it legally. An interesting debate for the establishment of a higher level of social protection in Europe is that regarding the proposal for a EU Directive, a legal tool that would be binding on European member states, introducing a European minimum wage.

KEYWORDS: International Social Security - Social Legislations - European Directive on Minimum Wage 


\section{THE INTERNATIONAL PERSPECTIVE OF SOCIAL RIGHTS}

Studies on social rights have been traditionally framed by legal scholars in a national perspective. Both contributory and non-contributory social protections - the first based on an effective labor activity, and the second decoupled from economic activities and rather based on tax deduction, as a form of assistance to third subjects in condition of need - are traditionally ruled on a national base, to be administrated at several different levels but being centered on the nation-State.

Such an institutional basement arose at the beginning of the industrial era, when the social category of dependent workers started to be represented politically, having reached an autonomous position in society, which called for a new coverage in social security, insofar they were not joining anymore the old protections as typically linked to familiar relations and to householders' allowances, to nobiliary entitlements or to the few professional ranks having a security management of their own, like medical doctors or lawyers.

The first Italian Act covering workers' injuries, dated 1898, defined the worker for social purposes as the one "who is employed outside his or her premises, permanently or temporarily, with fixed or piecework remuneration, or anyone in the same situation who supervises the work of others, even without partecipating in it, if his or her salary does not excede a certain amount and the pay periods remain within the month" (E. ALES). Since then, the scope of social protection did not exactely fix its borders within dependent work only (indeed, supervisors, who are mentioned by the 1898 Act, cannot fit the traditional category of hierarchical dependency that the Italian Civil Code in 1942 set as a criteria to ascertain subordination) and later found application, to much extent, to categories of workers being autonomous, like artisan and merchants, or registered intellectual profession as that of lawyers.

Nevertheless, there are several indicators of the fact that, nowadays, social security cannot be clearly comprehended anymore if we remain into a statutory-national perspective.

First indicator, if we consider the matter from an overall point of view, is the tendency of legal studies and public policies to mind law and (global) economy - wherein law is supposed to be applied - as chained by an inestricable link (R. A. POSNER). The welfare state was born to face poverty in lack of labor entrances, but before that, it needed to face the failures, imperfections and obstacles "that prevent the community resources from being distributed in the most efficient way"; the social matter still presents itself, as one of bringing "into clearer light some of the ways in which it now is, or eventually may become, feasible for governaments to control the play of economic forces in such ways as to promote the economic welfare, and through that, the total welfare, of their citizens as a whole" (R. COASE). A major factor rising the need, as well as the opportunity, of considering together law and economy today, is digitalization of economy, which brings along an international perspective easily: "digitalization (...) intensifies the societal process of individualization in general, and it influences a specific type of social relationships, namely industrial relations, in particular (...) it allows for new ways of communication, more flexibility and more mobility; it enhances globalization as territorial bounderies of human interactions lose their relevance, new employment patterns are emerging (...) and those changes in the labor market pose, in turn, challenges to the social protection, in particular if social protection is organized via traditional forms of social security" (U. BECKER \& O. CHESALINA). 
Second indicator of the importance to adopt an international mindset, is the process of legal recognition of social rights at the European and international level, whereat the integration process settle fundamental social contents to be granted to every human being regardless her or his specific regional circumstances: at those levels, conditions and requirements and/or entitlements are not stated already, they remain for the main part to be 'specifically' defined for being executed, but any execution at the local level is going to be not released regardless the international legal system of which our Constitutions is giving recognition.

Third indicator, is the tendency to search for higher level of protection and better treatments outside the national borders, because of the impact of democratic movements, and by way of trade unionism and collective bargaining also, by way of transnational agreements that allow to follow certain economic flows meant to be fruitfull in terms of workers'partecipation, in terms of bargained welfare, in terms of potential improvement of both the living and working conditions of the interested groups and categories. Such a tendency for activism of trade unions, pursuing both non discrimination and specific social goals, together with redistribution of economic increasings, has been encouraged by the 2014 Italian Reform (Legge n.183/2014), which might be well enanched by way of transnational bargaining.

The State souveranity is told to be stressed by new emerging conception of social rights, especially after the COVID-19 crisis; it has been estimated that "there will be a new demand for social security - 'you living safely in your warm houses' (...) - which will be necessarily addressed on States, and which the States will redress upon mondial organizations, whenever they could not cover it" (S. CASSESE).

Thereafter, it is not bizare to have some worries about the tendency to internationalize our concept of social security, to connect development of our welfare outside the national barriers, far from the political stream that associate security to nation-States. How far is it possible to secure social rights from a comparative perspective, as the influential contribute by Roland Coase on development of social rights was essentially proposing? How far can we fruitfully use an economic comparative perspective before imposing any deducion against a business that is producing both social benefits and a negative impact? The consideration of reciprocal relations in any given context can bring up the opportunity of social/legal rights adjustments to emerge which is totally more convenient for the all community; is this perspective always feasible? To simply reply that is not feasible whenever a closure is set by one party on consideration of the opposite/competing parties' interest or group, is not covering the whole of possibilities.

According to a conservative view point it has been argued that Marx, when predicting the explosion of a fight between different classes, far from being himself wrong, only indicated the wrong century, because that explosion would be rather about to happen in the XXI century, sadly, when "international solidarity of workers will not be set in place, and the classes that just cannot move around the globe will not get united" (contrarily to Marx's hopes perhaps) because "they do not have a real interest in doing that". Here is why nationalism would be here to stay, and not necessarily grounded on irrational forces, leaded by people scared by a global flow that they cannot control, contrarily, as a rational phenomenon meant to limit the possibility of stronger groups to undermine some other group interests. Nowadays, more than a conflict rising while distributing productive factors, the social issue stand up at a deeper level that is clearly not only economic: "complexity of the labor market makes the abuses on workers much less easier to define, and to re-establish the 
relationship between the workers 'input and the value of their work is rather impossible" (...) what today can be called a class is the common sharing of opportunity and riskes, associated with hopes and fears that impact over the evaluation of one's personal life opportunities (...) revealing that is the class (or the group) - more than norms, values and level of moral evolution - what signs the difference between globalist and nationalists" (Y. TAMIR). The new frontiers of labor law, promoting self employment and distributing dependent labor occasions by way of technical tools that allow a departure from a regional/national territory in a much easier way then it was possible in the old factory, a labor law that has reached its original aims of delivering people a range of freedoms that was not predictable a couple of centuries ago, that theoretically enables young generations and women to take the lead of their own life, not necessarily dependent on familiar relations, this labor law scenario is not anymore the place wherin the social conflict can directly be found: in the past, labor unions were fighting against capital owners to get a higher remuneration and more time off (only), while today the matter of social security and health in the workplace is increasingly interferring with people's life, family balances, and general interests that can arise everywhere public bodies are called to intervene at a substantial level.

In light of these preliminary considerations, the matter of linking social rights to citizenship requirements, and territorial bounderies, shall be studied by newely analysing the structure of the relationship between social security and labor rights. On the one side, labor is ruled by political and private actors in such a way to grant and to extend those freedoms and liberties that labor itself is materially creating ahead, rationally, increasingly not discriminatory and according to more or less predictable objectives, rules, and results; on the other side, human beings do have, and will always have, to claim for their personal needs, health, future perspectives, psychological conditions, according to their own social identities, which is an operation that requires the presence of divisions and borders. If we were all belonging to the same big group or family, our peculiarities as individuals having particular needs in respect to the other members, and in respect to the other groups and families, would be irrelevant to the purpose of social security, indeed. Similarly, there is the necessity of juridical persons to define their own identity for being functional, like national States or groups of people, which is a cultural operation that, although grounded upon an artificial construction, has the effect of allowing exercise of powers and functions according to objectives and politics that are relevant for that entity, more or less temporarily. Already in a 1985 call for debate over democracy and political economy, tensions between individual and class-related interests emerged and set a challenge to left-oriented parties: it was underlined that "what shall be abolished are the limits that social disequality set on individual development, on the free realization of the infinite varieties of attitudes, on the full expression of differencies. This is a fundamental step still to be moved forward by the ideology and the practices of the left parties, which is moving still, when it moves actually, according to rigid logics for masses and classes, proposing models and collective solutions there where it would be rather required operational flexibility and projected articulations" (P.GIOVANNINI). Such political tension, that has repeatedly lead to the option of bi-partisan governments in European democracies during the last decades, impacted legal systems nonetheless, and set them under attack in their capacity to organically rule over social phenomenon: "we would certainly benefit from a conception of social and labor rights that is organically conceived and ruled, although, we would face a conservative theoretical model, as Weber was already very clear and aware about, saying that a social organic ethic is most of all a power eminentely conservative and setting barriers against any possibile revolution, while an 
authentic religion of 'virtuosi', on the contrary, might have revolutionary consequences" (A.SEN). According to an Italian study focusing over values and regulatory technics in labor discipline, the increasing application of new technologies to the labor market suggests to mind labor protection by having regard, firstly, to the work-place wherin the work is actually performed, the work-place that can be defined as the place where the worker is effectively and materially present to make his job, and that such a starting point is leading to consider three different possible scenarios wherin both active and passive policies for social protection could/shall be newely considered. A first scenario is one promoting the highest level of solidarity and cultural integration amongst workers and capital owners (the so called "industry 4.0") wherin setting goals and frontiers is part of a common sharing of risks and opportunities; a second scenario can be seen with adoption of automatic forms of management applied to a common material space of work, territorially definible (the type of work-place that the Amazon model is realizing, for example) wherin it turns back to be fundamental the distinction between dependent and not dependent workers; a third scenario would be covering the rising of platform capitalism model, wherin rider-workers are allowed to perform regardless to the place of work, till be requiring to performe on the street, presenting a preliminary need to be protected for their health and safty (B. CARUSO \& L. ZAPPALA'). The geographic borders of the work-place are evidently still relevant once considering both active and passive policies and legal techniques to the purpose of protecting workers. Insofar passive policies can be considered as actions compensating the lack of working chances and for active policies those increasing the working opportunities, not only the allocation of a minimum social protection but the realization of a better work performance as well could turn to be a matter of crossing borders for anyone to whom the local/domestic management would deny the minimum standard or the higher remuneration. The working place is thus essential to be defined at a physical/geografical level, while the normative legal system can be part of the deal between the worker and the administration to which he or she is referring for labor protection. What is going to be in point are the facts that describe the employment/social relation, like present and past working experiences and learning skills, residential and family conditions, political orientation of the involved administrations, presence of collective bargaining, and basic and complementary social security positions too. At such a factual level the jurist is able to ascertain the nature of the nexus between the relevant work positions (individual and collective) and the social rights that are supposed to be defined, qualified and interpreted in any single dimention and according to the relevant/geografical legal system for them to be enforced eventually. The productive nexus that chains work - work meant positively as an activity letting the person gain a set of rights - to any social position is going to be better captured by use of cultural categories that particularly fit the complementarity of such relation as a whole. If social assistance is meant as compensation to labor opportunities distribution being not satisfactory, the work personal nexus and the social personal nexus cannot be comprehended separately, moreover the reason of any social exclusion must be investigated in its cultural, psychological, economic or multifactorial roots. Also legislation shall be as flexible as to possibly cover any complementary nexus that is relevant for its social (normative) purposes, considering that time to establish such a nexus might be subject to a high degree of variations according to the circumstances amongst which social exclusion and social vulnerabilities are emerging. Indeed, the nexus of complementarity between work and its social protection rises very differently according to the cultural context in which it is investigated and the cohexistance of different cultures in the same social context might require an even more deeper investigation over single social needs and supposed necessities. The nexus of basic complementarity itself, 
that reminds a concept of organic relationship, might be challenged, so far as society develops according to social progress and new technologies: only mind that today the need to become parents can be satisfied in laboratories (but not at the same conditions in every country) and according to a progressist culture also a single person or gay couple can become parents by help of women who are conscious and happy to hire their body for money, to the purpose of letting someone else child to born (but not in every country, for example not in Italy). Considering the different culture wherin the nexus is to be found can be highly explanative of how social security might be differently perceived and thus implemented. According to an ortodox Chinese view such a basic complementarity is expressed in terms of 'yin' and 'yang', eventually conflicting, where the first (the 'yin') reminds the material sphere of the human existance and the second ('the yang') reminds the spiritual sphere instead; in such a 'Chinese' view it would be appreciable the social contribute of a labor activity yet being not fruitfull but bringing to an increase of some material factors' productivity nonetheless, which perspective implies that any social exclusion is better understood as a derivation of a spiritual approach considered detrimental upon the material welfare of the community, thus finding limited or not admissible protection by the legal system. Contrarily, according to a purely Jewish perspective that denies the concept of trinity (as well as the figure of Jesus as the messiah) any social exclusion is theoretically unacceptable and to be rather explained as a misinterpretation of the law of the fathers. Irrational choices too have always being impacting over economic settings: for example by remaining on a strictly economic setting of mind, there are empirical evidences that digitalization of modern economies increases the impact of not consciouss choices in the process of economic growth and its distribution; although "economic growth is the most important macroeconomic determinant of the changes in inequality in the long run" (G. MALERBA), the digital economy is giving the perception of being "alone and free of acting" while different effects keep on actually be following according to the economic rulers (an example of such a relativity can be appreciated before some determinant operators as Uber, considered by some legislator and international rules as offering a transport service while its management refers to a service for delivering information).

Yet in our secular and supposed to be democratic states, working upon rational structures and human rights plain protection, there have been, there are and there will be several substantial values that can be conflicting and that are pursued within social dynamics that might keep separated the labor productive dymention from social rights achievements, preventing easily social rights to be enforced, regardless to the availability of resources. Most of the times such a result derives from a regional or national interest composition, emerging to affirm a stretegical/political power as for distribution of administrative supremacies and identities; it is indicative of such tendency that the European Charter for Human Rights does provide for a flexible, ranged, temporary and territorial changing application of the Charter itself on request by each member state to the secretary of the Council of Europe (see protocol n. 12, article 2) and that the 1952 ILO Convention C.102 on social security minimum standards is doing something similar, as it will be remembered further below. Also indicative of the practical and substantial varying application of the European Charter for Human Rights are the difficulties in the dialogue amongst high courts at the international level, where international courts have found themself struggling before the supremacy just gained by national high courts; decisions from the higher courts have clarified that the European Charter "does not grant the right to a certain living standard" nor "the right to acquire the possession or to receive social security benefit or pension payment of any kind or amount, 
unless provided by the national law" (ECHR, Carson c. United Kindom, 2010.3.16). It is remarkable to precise how "the evolved role of the judiciary is allowing, today, that a judge is called to build the highest protection to the right which is the object of his judgment, by way of integration between the Constitution, the ECHR, and the European-Nizza Charter, in the perspective of the maximum extention of liberties: such a perspective is feasible since every Charter does establish the minimum protection, not the maximum of the ricognized rights" (C. SALAZAR).

\section{LABOR AS A SOURCE OF SOCIAL SECURITY}

Essentially, the matter about the limit of labor as a direct source of social security cannot be eluded: we cannot avoid to answer this basic query in a context of labor law legal systems that are stressed at finding new definitional categories to rule over employment evolutions and implications that just cannot fit many of the traditional forms, from definition of 'dependent worker' to that of 'employer' up to the varying personal and technical nexus that make up an employment relation. "There are good reasons in favour of decoupling social protection from economic activities, although better reasons are still against it. In the end, it is a question of how to organize the cohexistance of people in a stable, freedom based political comunity" (U.BECKER \& O. CHESALINA) and it leads to put the focus on both emphasizing 'self responsability' and including companies in the assuming of a social responsability. So, although provocative, since of course first answer must be yes, labor 'must' be a direct basement for social security, the query rises the need to be aware of the philosophical structure that stands at making such a basement. The philosofical issue stands for jurists in particular, who know how labor is economically fundamental, but also that social rights have been traditionally and widely delivered outside the labor market.

To theoretically set social legislation apart from labor law is the way scholars have, in the beginning, dealt with the matter. But to set them apart, only because social legislation "could be losing something (in being treated together with labour, n.d.r.), insofar social rights existance, entitlement, and exercise could be conditioned to their economic sustainability with regard to collective needs and, mostly, to enterprises' needs" is an argument that does not consider the inestricable link between law and economy, and contrasts the assumption that "the principle of 'conditionality' is essential to the function of law itself" (E. ALES). To mind the function of law as something working upon conditions, means to simply consider all material and immaterial goods as a limited entity, to be ruled in accordance with their availability; in such a legal perspective, what, in reality, is infinite, and not measurable too, is supposed to be conditionally recognized nonetheless. For example liberty, solidarity and public health, although unlimited in nature, are to be considered limited because of any possible opposing element which is relevant in the given social context. So if we keep in mind the inestricable link of social rights (and social security) to work, it is perhaps easier to understand the former (social right) as a sort of shadow of the latter (work) for them both to be more easily be recognized and connected.

Such a jointed consideration implies a clearer understanding of how politics is impacting society by way of its discretional power - at the legislative, administrative and judicial level: discretional power mix the logical precedence of labor, as a factor producing economic and social value, with the necessity to deliver such value as a whole, letting that the nexus 
amongst benefits, assistance, and value itself, does emerge. Understanding social security means to understand the historical asset of social relations that makes up the administrative schemes, public and private, which will actually procure any social help as needed; while any general norm states the social right as an aim, definitional 'self executing' categories giving theoretical preference to a person or group rather than to another would be going to have no great utility in coping with future conditions of need, it would be like a legislator stating over who's got the right to be protected first, whether the workers' children or the working parents, whether the woman or the man, whether a group of pensioners or a group of students, as well as a category amongst different professional cateories. The legal frame has the purpose of orienting the operators avoiding to release unreasonable social treatments; not necessarily equal treatment is been the objective of the Italian social legislation, for example, while substantial equality in the sector of public health has been pursued, and 'reasonableness' has been remarked by the Italian judiciary as the main parameter for any social security legislation to be coherent with other fundamental rights.

Explanatively on relation between labor and social legislation, it's been argued that a citizenship minimum wage - as that introduced in Italy in 2019 by statutory law (Decreto Legge n. 4/2019) - is not consistent with our Constitution that is grounded on labor (article 1 Italian Constitution), insofar such policy would undermine the dignity of any person who is so brought to be assisted rather than to actively partecipate in the social life. Contrarily to this view point, it cannot be denied that there is always been a range of population having a negative conception of work, because of several impediments that just prevent, not only the finding, but the preliminary search of a feasible occupation: cultural and psychological barriers, family conditions, specific disabilities, etc.. Such a perspective is coherent with a concept of work having not necessarily a positive meaning, rather evidencing an act of effort, as a hard activity opposite to human beings freedom. By the way, the European Charter of Fundamental Rights affirms expressly the prohibition of any forced labor (article 5), and according to the Italian Constitution, social security is to be delivered to those who do not have the means for a living, regardless to their job position (article 38).

To the purposes of this paper, consideration of work in its negative image (which partly corresponds to an overcoming of the contributory vision of social legislation, rather favouring a beverigian model), would have the disadvantage of making more difficult to discover the (legal) nexuses that base human liberties, for these latter needing to be materially grounded elsewhere: if not by work, would human liberty be granted by the State? So that by going beyond the State we could face some risks? Is it granted by the net of social relations? But all human interrelations imply an assuming of a social risk, so who's in charge for coping with any searched protection remains to be defined. Is liberty granted by law? But the law is always exposed to different interpretations, unless it arrives to be applied by judges of last instance. Someone could force the discussion to close the gap by saying that human race protection can only rely on the Lord charity, as the true funders of modern capitalism were arguing within the protestant Reform in 1500. In other words, if we want to consider work inside a theoretical perspective of freedom where social rights are granted universally rather than on a narrower conception of obligations and duties, emerging from the labor contract and from its assuring contents, from its boundaries, its social implications, then one might argue that we would face the risk of entering the never solved conflict between natural law and positive legal law. The former (a conception of law based on natural relations) covers 
the need for security along the human race, and is the same everywhere, while the latter (the positive law) is indifferent to natural conditions and can vary according to time and places.

Nevertheless, if we remain on an idea of work wherein freedom (of all the concerned comunity) is supposed to be included, rather than excluded from the topic which is under concern, an idea of work that is not mediated and that rather minds labor as the source of liberties, than it is going to be easier to consider its legal framing (labor law) as a tool directly solving the matter of distributing social rights, actually effective on tackling the social conflict generally rising in the periferies around each society. Along such a perspective, it's been argued that "the role of social and economic policies is that of giving a frame within which the individual capabilities, meant as effective economic freedoms, are realized in accordance to some restrictions fixed by the given resources. The Institutions, as well as the markets and the other economic coordination mechanisms, are considered, from such a view point, as tools to be used on this purpose, not as tools themselves. The same principle applies to social rights and re-distributive/protective welfare systems: they are tools to strenghten the liberties of the single person" (A. SUPIOT). Hereafter, we can understand how the spiritual dimension of work, which Weber widely studied, the 'living work', is going to develop an ongoing process aimed at reducing the time of "subordinated" work activity while enlarging the scope of self employment, in a consideration of labor as a scientific activity meant to serve society more than an alienation of time - as it was, instead, according to the Marx's critic approach (M. CACCIARI).

Once we fix to this legal-positive perspective the matter of work can be framed as a matter of social citizenship more than a matter of (social) alienation, and privation/limitation of freedoms: the right to earn a salary is not ultimately relying upon the master, nor on the 'good father' will to accomplish his obligation toward the diligent one (child) having worked in his premises, it is rather the right of the diligent man having worked wherever required and having produced a spiritual/material activity so recognized as such by the legal system. The right of a worker to be employed in consideration of his familiars needs is not ultimately relying upon the head of the family's will (giving permission to work elsewhere), but on the duty of the employer to not discriminate him because of his familiar conditions (having the right to be treated justly).

From such a perspective, the main point is attachment of workers to their own work: the difference is made by those loving their job, feeling thus not alienating their life time, and those who don't, reason why the social balance should better be found "in the very centrality of life, which implications and needs shall be found, within work, via work, because of work, not only on work as delivering goods and leisures to be consumed" (P. GIOVANNINI). Again, Weber's studies turns to be of precious help in searching for a convergence in legal frames needing to be seattled along the burning path of politics: he suggested that both the ethical approach (what is believed to be done) and the responsability approach (one's own action liability) are to be faced, rather then taken as alternatives (M. BONOLIS \& L. SABETTA). Contrarily, the Machiavelli's doctrine set a theoretical opposition between morals (beliefs) and politics (responsability) that supposed an everlasting opposition of foxes angainst lions that translate itself into the necessity of an historical alternation (and instability). Correctly it has been evidenced in the weberian approach a fundamental shift in considering the political action, requiring personal skills and cultural mindset ready to adapt to changing and challenging reality, more then animal strenght. 


\section{DEFINING SOCIAL LEGISLATION}

It is important to define what we mean by social legislation because it is a significant operation to update the perimeter of puplic and private protections of workers and citizens in the globalized scenario. Both at a national level and at the European level the first impression we have is that we are far from any organic legal system just capable to be read and applied simply in a given social context. The ambiguity of any social legislation stays in the fact that its sources have always been, in the form we use to know them nowadays, since their appearence in late 1800, multilevel: social legislation rised from the corporative experiences of workers' unions and it has laterly developed in statutory legislations that have increasingly enhanched constitutional principles of general solidarity - implying that public (and private) social institutions must serve not only workers, but all citizens as well. National and international jurisprudence and the European integration have then forced the extentions of social protection to citizens working abroad and to migrants working in the country independently from their nationality.

"Freedom from being in a state of need" is what justify any social intervention from the legal/rational point of view; to realize such a freedom always "implies the adoption, on the part of the legal system, of concrete initiatives having a positive character, being addressed to the specific aim" (M. CINELLI). Differently, what explains a labor law intervention is rather the purpose of granting occupation, occupability, non discrimination, which could have the effect of producing negative impact over single workers or group of workers too: prolabor statutory ruling acts mostly at a macro economic level by promoting occupation in some sectors, thus on detriment of others, and even anti-discrimination acts might have the effect of limiting the working chances of someonelse. Similarly along any occupation progress implying economic development, also innovation and technical innovation, which are themselves factors that impacts the labor market on detriment of some already established job positions, some negative effects on working condition might be following nonetheless. To ascertain whether such detrimental effects on workers are happening already, or might be so, and to which extent, for any social intervention to be minded as opportune and compensative, it is fundamental to investigate over the link that exists between social security and the flexible economy wherin labor relations develop - a link that the legislator should better take as inestricable.

The list of social rights that we can find in our national chartes and in the international social charters - on going and inclusive training, active policies to support employment, information over employment minimum standards, social dialogue taking into account the need to balance work and family life, security in the work place, unemployment and retirement allowances, health care and fundamental services like water, energy, housing, and, the 2017 European Social Pillar is now expressly referring to also digital comunications as a basic social right such a list gives an abstract description of what we should mean by an individual social right acquaintance; that is a baggage that, to the purpose of its practical recognition, as well as for any single applicable right enforcement, must be historically collocated in its legal connections to both the community that is involved, and to its economies. Both the entitled recepients (workers and residents or citizens) and those delivering the benefits (public and private institutions) might well have established or being establishing an organization of means of their own, they could be organizing basic or technical tools that allow the needs to emerge and the benefits to be delivered. Be it the case, it resulted that the legal system for social security would be able to operate effectively once these two different organizations, 
made up by people and producing factors, are openly communicating the one with the other, while there would be going to be a shift, and a risk for a real need to not be covered, whenever a closure is preventing from being the need realized, captured, and be coped with. If we assume that social security is effectively set in place at the presence of this two basic, but also possibly very complex, organizations, defining both the social perimeter being relevant (for example a family made of two persons, or a young boy having no personal nor familiar resources) and the economic means (for example an economic or medical support, or a training solution to access a labor position), then we start to give a material meaning to the general purposes of the legal system, as well as to the general purposes of the mentioned international social security standards, wherein abstract remedies are preventionally thought to cope with elementary needs. Once the social organization stands in place, the social right is not anymore an hypothesis, it is a remedy, the norm can produce the legal effect flowing from the juridic legal order as an operating mechanism.

Such approach to social security brings us to consider some juridical tools just needed to basically let these organizations to be operating, rather then being trapped within (cultural) barriers of different nature: first, it could be used the concept of "mutual recognition" of the organizations involving people and means, second, the concept of "agreement or contract" that might stemp out from such recognition and matching of interests, third, the concept of "remedy" as a substantial, and possibly also procedural solution that has been established at the normative level to cope with the social risk, that is the positive action bringing the person, or the group of persons, out from the state of need. As a fourth element, I would add the "sharing of information", standing at the basement of any social dialogue leading the involved structures to be helpfully operative.

3.1 Mutual recognition. So the first element that we use to verify whether a system of social security can be told actually standing is whether the involved parties do recognize themselves in their own different (if not strictly opposed) position. At the very beginning of (industrial) workers' movements, that were opposing to capitalists and householders, was the mutual recognition of these economic actors as two agonistic social organizations; this is how labor unions were born and this is the basement upon which collective labor law is developing in constitutional democracies till nowadays. Recognition can be implied or expressed, it can be legally ruled or formally bargained, but what matters is that, to be real, it has to be substancial, de facto in place.

3.2 Agreement. Whenever the mutual recognition reaches an agreement, then we have a second element for social security to be told standing, and the more the agreement is expressed and clearly stated, the more the agreement can support an effective enforcement of social security; instead, in case of a resisting conflict, any implied term of contract will be requiring a higher probatory burden before being set in place and its social security contents being delivered.

3.3 Normative remedies. Third juridic element granting social security, the most relevant from an ex ante view point, watching over the necessity to enforce any legal assets of rights, is the range of remedies that are set to solve or to prevent any social issue, and procedural remedies nonetheless, like alternative dispute resolution methods, professional negotiation or arbitration, courts proceedings, which are called to apply norms which have been set more or less generally or specifically, giving coherence to constitutional principles and assuring a social-economic development that can be supported by the collectivity. Here we can 
appreciate how social security is much dealing with matters that require both recovering and preventive approaches to social needs, to be better furnished at an administrative level, while to claim for social security at a procedural level leads very easily to a lack of intervention and a to damage, or to an increase of the damage already. It is at such third point of social security operation that we understand the possibility to connect benefits to workers'right and contributions, structured upon an assurance type model that we recall as the "Bismark model", or to connect benefits to a more generalist view (the so called "Beverigian model"), based on fiscal contribution and having the aim of protecting directly not only workers and their family but more broadly any citizen who would find himself in need because of age, disabilities, lack of family assistance, political persecution etc.. Also, it is here that we can value the impact of any supplementary/integrative social security system, that can be more or less connected with the basic one, and also can be appreciated here the space that stands for private assistance. As for the scope of social security, it is then fundamental how the architecture of the social organitations, operating as legal institutions, is considering the classification and status of workers: subordinated workers are used to join different kind and level of social benefits from independent workers, and the difficulties that typically stand for practically qualify some professional categories that fit both subordinated and independent work criteria might be taken as justification for eluding expectations for legally recognized social rights (on this particular point see the section below dedicated to the proposed European minimum wage).

The traditional model of European social security distinguishes remedies grounded on workers' self contributions - prevaling in Italy since the very beginning of its statutory recognition and being newely encouraged within the 2014 Reform, by way of collective bargaining promotion - from remedies grounded on general tax deductions, like the measure of a minimum citizenship allowance that was introduced in Italy in 2019 (D.L. n.4/2019), which entitlement requirements are to be found regardless to the person past contributions as a worker. To make up a development of corrisponding economies operating upon a redistributive scheme (wherin those who works, or works more, are called to a solidarity in favor of those who cannot work as well) or upon a capitalizing scheme (wherein those who works and contribute are be called to save, and correspondently to invest their saving with the perspective of increasing economy and employment level) is evidently possible within the contributory system only. On the other side, the non contributory system minds its own function as one producing a re-distribution of income. Remarkably, both at civil law and common law, the whole of social and economic rights is not dependent on a labor contract or a job position only: social single rights are accorded to people on the ground of many different conditions of their own peculiar position in society, be they linked to family relations, to public and private associations or organization, institutions recognizing them a living that is justified on facts and status others from working activities, like heredities, family maintenance, accidents and injuries, even crimes committed, as it happens to prisoned people. Thereafter, to materially deliver social rights can be originally both a matter of subjective rights, thus a matter of recognition of individual entitlement coming up from private mutual agreements, and a matter of legitimate interests to be dealt with by public administration, that can only be allocated by way of a discretional use of power by the public body. The borderline between what turns to be a subjective right and what a legitimate interest is much depending on both the individual or group position at facing the public body that is supposed to deliver the sought benefit and, increasingly, upon the actual behaviour of the involved subjects in filling the regulations'requirements (social legislation conditions); 
the public or private bodies that stands in position to deliver social benefits are to be considered nonetheless in such a dynamic pathway. Evidentely "the extent to which solutions actually open up to possibilities in order to rearrange access to social protection, and what solutions are appropriate, depends very much on the institutional pathway that exists in a given country” (U. BECKER \& O. CHESALINA).

Every person is recognized preliminary by his or her legal system in accordance with his or her birth, he gets his general juridic capability at a certain age, usually at 18 years old, and since then, he is capable to pursue his economic independence both remaining within the familiar relations or outside from them, and relevantly for social security purposes, he is going to be able to opt for forming a family of his own. Labor and social legislation are recognizing any phisical person as a unique juridic entity before the public administration, both for social contribution and for taxes legal schemes, and this is what is going to grant any person the corrispondent fundamental social rights and freedoms. The position of any citizen can be then considered for many other given purposes, and different functions can be given to him or her for achieving several aims from the legal system nonetheless, from any comprehensive normative system made by different sub-normative systems that can clarify and specify single rights and duties, by executive mechanisms in the different disciplines as those connected with active labor policies, immigration policies, business sectors and so on. But such plurality of functions is not leading to any duplicity, nor to any moltiplication in the consideration of the same single person before the same administration delivering social benefits. Such a minimum statement in the consideration of any possible recipient of social rights is not, and should be not, shadowed in a perspective of a legal frame that is international, that is considering the global and European integration processes as a way to multiply subjects and requirements for social security. The European Union, as well as any wider or different international legal frame, does present administrative and political choices not differently from what it happens in a national frame, it only lacks the ultimate remedy to force a solution, while the nation State typically does not, having the State its military body. But it has to be minded that any social intervention, because of its prime and ultimate aim (coping with a person's state of need) is widely one calling not for repressive measures: only in case the need was directly linked to a criminal conduct, preventing any feasible alternative for the person to get the sought freedom, then a repressive measure could be reasonable. What is more complex, at the international level, in respect to the national one, is the type of connections and intermediation amongst the different level of representations: the increased plurality of level of representations, meaning different level of managements and administrations, might impact over the execution of a right or a duty, for such execution implies the need to specifically recognize the single being, the single worker, in his or her subjective position, and of course such recognition is going to be more complicated in case of international elements (double citizenship, working experiences abroad, foreing certifications as for skills or contributions and the like). But anyone thinking about a foreign legal frame as a way out from local guaranties and responsabilities is misunderstanding the essential function of social security whatever the level.

So both at a local level and from an international perspective, the searched remedy is to all effect what requires a consideration of the single person in need in her specific context, education, skills, national origins, future perspective and the like; here, what at a labor law level should have no relevance (as for accessing or maintaing a job position) like family status or sex orientation, shall have a carefull consideration in order to achieve the substancial 
balance that social legislation tends to pursue. This is amongst the reasons why social policy developed later in Europe and why social security is normally requiring a reduction of the material space wherin it is supposed to be operating, while capturing any physical person or group of persons to be identified in accordance with their own peculiarities and social circumstances: the member States themselves, as the European Union, are intervening on a principle of "attribution of competences", as well as on the principle of subsidiarity affirming that the body standing above on the hierarchical structure of the bureaucratic organization intervenes in so far the one standing below cannot intervene itself - and this is naturally calling for a local, regional and territorial administrative coverage of any subsidy and social action to be delivered materially. As we will remark below, the rule to apply the law having the nearest connection with the concerned persons is left as a cardinal one in Italian private international law whenever there would be disagreement on jurisdiction.

3.4 Exchange of information. As a fourth element granting social security as a juridical tool, to be certainly implemented, is the sharing of information amongst the charged institutions, be them unions, public offices, stakeholders playing on the same scene. Exchange of information would turn to be even more relevant once any forms or procedures of the so called 'societal constitutionalism' would be set in place to solve or prevent social risks and social exclusion. Societal constitutionalism is a theorethical framework to cope with situations of conflicting values by way of a dynamic perspective (S. CHIGNOLA): whenever the traditional asset of the legal systems as involved would not be capable to give a satisfactory result in terms of subtantial justice, an alternative artificial space could be experimented (without excluding the path of traditional formal justice, that is based on the State supremacy and is centered on the single person individual right) to the purpose of increasing the conflicting parties' opportunities to adjust their mixed interests, letting them to actively partecipate in the normative process that establishes definitional categories to suit subjective positions and necessities in a feasible and more flexible manner. It has been argued that modern societies challenges "may lead to a more universal, and at the same time more restricted, role for social security, leaving room for more variety as regards supplemental protection" (U. BECKER \& O.CHESALINA) and this finds several confirmations, for example by the 2021 Italian Reform supporting families who have children not autonomous yet: it re-shapes the range of specific benefits, and supplementary benefits, already standing to support people with children, by introducing an alternative, universal, unique check covering every family with children having up until 21 years old.

\section{BASICS OF ITALIAN SOCIAL LEGISLATION IN AN INTERNATIONAL PERSPECTIVE}

Now, the Italian Constitution states that the Republic is democratic and based on work (article 1), which is a statement already implying that work is the ground source of any right that our democracy shall finally recognize; also, it is therein implyed that non-working social positions are grounded on working once. To make such a point explicit, considering a theoretical closed national economy, it would be correct to affirm that the social condition of unemployed people and children are finally linked to the output of the working once, that the social condition of pensioners is relying upon their own working contribution, or upon the contributions of those still working; and a legal fundamental nexus with work would nonetheless to be found in the position of people who are temporarily or permanentely living 
out from the labor market, which is what rises the whole matter of undeclared working activities, or the condition of people staying in jail, relying upon the job served within the hosting penitentiary institutions, or the living of any injured people, who might be relying upon the work of those who deliver insurance coverage against damages.

At the same time, the Italian Constitution also states that social security is to be delivered regardless to the job position of those who do not have means for a living: "Every citizen having not the ability to work, being without the necessary means to live, has the right to maintanance, and to social assistance" (article 38 co. 1); social security is disposed particularly for workers: "Workers have the right, in case of injury, illness, disability, old age, unvoluntary unemployment, to adequate means to be provided and assured for their living needs" (article 38 co. 2). Moreover, "disable people have the right to education and professional training" (article $38 \mathrm{co} .3$ ). It is up to bodies and institutions established and integrated by the State, to cope with the social tasks as provided in this article (article 38 co. 4). "Private assistance is free" (article 38 co. 5).

The choice at philosophy of law between natural law and positive law, just mentioned above as recurring through the phases of legal development, is what explains, to much extent, the many obstacles in giving to article 38 a proper application: the constitutional norm set the aims, but not actually the requirements to set them in place, and even less can it be told exaustive about methods or techinques that are meant to be used to allocate the social rights therin assured. What is constitutionally clear are the needs to cope with: maintenance and social assistance in case the person has not the possibility to work, adequate means for living whenever the worker not voluntarily loses the possibility to work, education and professional training for any disable people. The whole of this is to be covered by way of "bodies and institutions integrated by the State" meaning that the State can always be told as granting the coverage, possibly functioning, but not necessarily, as an integrative part of the social security organization, while private assistance is plainly free. Amongst the more explicative examples of how complex is to align social parties (collective) demands along the positive legal system setting requirements to access the benefits is the Italian set of acts covering unemployment and collective redundancy in particular: since the Constitution approval in 1946, and particularly at the beginning of the economic crises in the Seventies, there were decades of caotic legislation, giving full derogatory power to the Ministry of Labor and workers' representatives, running after any sectorial crises, coping with trade union's pressure before every crises as before a public order disaster ("public order must prevail since the State cannot accept poverty, which is itself a social risk to be not allowed (...) the unemployed who does not have the means to feed himself is going to commit a crime, tells an old ideology"). But article 38 is not granting an everlasting coverage out from the labor market: by mentioning unvoluntary unemployment it sets a temporal limit to the necessary protection, and makes clear that the protection must be not only economic, but dynamic too. This means essentially that those being angry must be feed immediately, but such a social intervention cannot be realized as a lasting free restaurant, it is required a dynamism in helping the people enter back in active partecipation in the community for their own sake.

The 2014 Reform (L. 183/2014, the so called Job's act), which efficacy has just begun to be actually valuated, had the purpose of rationalizing all supports standing, on the one hand, in(side) the employment relations, and on the other hand, those standing outside the relation, for getting back into the labor market. That Reform was developed by way of D.L. 148/2015 on social support during the employment relation (ruling over work suspended or reduced, 
insofar a concrete perspective is standing that the business will rise again); D.L. 22/2015, ruling social support for lost of employment, requiring a minimum period of contribution by the worker; D.L. n. 150/2015, ruling over active policies to encourage employability just newely coordinated around a national agency and a personal agreement with the worker, aimed at the latter professional training and re-employment.

As for social security in case of international relations, in cases of workers' circulation, it is relevant for Italians working abroad as well as for other Europeans working in Italy, the European direct binding regulations that have armonized national legislations to the purpose of preventing any detriment from the effective realization of such common (labor) market which is supposed to be a zone wherein dependent and self employed can freely move and establish their businness without being discriminated or loosing their social rights because of the only reason of not performing their activities in one only country (see now EU Regulation n. 833/2004, being enanched by Regulation n. 987/2009). Fundamentals of these rulings are, beside the need for open and fast communications between institutions and connecting organisms - better if by way of digital tecnologies - the right of any European worker to be not discriminated because of his nationality, the right to sum up different periods of social contributions connected to different places of work - which right is particularly important for retirement treatments - the right to receive the social treatment also from a residence place different from the working place, the right to be treated not differently from national workers also in case of non contributory benefits, although being limited in terms of residential requirements and budgetary limits, as well as involving the possibily for the paying (public) body to ask a refound to the interested social security institution.

Also the EU Directive n.1996/71 on posted workers shall be here recalled, as the act dealing with the possibility of the employer to send an employee by another employer standing abroad, to work there for a limited lenght of time; it recognizes the right of any posted worker, whatever the law applicable to the contract in that foreign country, to be granted minimum standards with regards to maximum working time and mimimum time off, holidays, minimum wage included that for the extra-work, requirements for temporary dislocation of the worker, social security and safety in the work-place, maternity and minor workers protections, non-discrimination as granted by the State where the work is performed. The EU Directive n. 2018/957, amending Directive n. 1996/71, while extending its coverage to minimum standards of housing conditions and travelling expences in case of workers living far from the place of work, now affirms that, to the purpose of determining retribution, it is applicable the law of the State where the job is to be performed, but once the lenght of posting passes 12 months, then also all the rest of the legislation, regulations, administrative and bargained conditions applicabile in the foreign place will be granted to posted workers nonetheless, except for any specific condition and procedure concerning termination of employment, fair competition rules included, and integrative social security systems; such a norm overruled Regulation n. 465/12, that harmonized social security schemes and affirmed that the foreign law is to be applicable for the early 24 months of staying in the foreign country, resulting that, in case a worker is posted, he will get the foreign law retribution for the all lenght of posting, and when passed the 12 months, also any other foreign law treatments will be applicable to him, except termination clauses, fair competition and integrative social security. The same EU Regulation n. 465/12 precised that a worker performing his substantial subordinated activity in two or more states will receive the social security treatment of his residency, while in case of non substantial activity, then the social 
security treatment of his domicile will apply, which is the rule of the place where the activity is presumably performed substantially.

As a matter of fact, the Italian administration for social security has been relying upon a prerepublican (and pre-constitutional) legal framework until the early nineties, when, upon pressure by also the Constitutional Court decisions, it was released the 1995 Reform of private international legislation (Legge n. 218/1995) which changed that trand into a more liberal and internationalized one. A couple of sentences declared the 1942 Civile Code to be partially inconsistent with the Constitution, insofar it was dealing with interpretation of contrasting laws: particularly, Sentence n. 71/1987 declared unconstitutional to apply the law of the husband's country at the time of marriage (article 19 of the 1942 Civil Code, now abrogated) whenever lacking a common nationality amongst married couples; and Sentence n. 477/1987 declared that application of the law of the father (article 20 of the 1942 Civil Code, now abrogated) was in contrast with the principle of moral equality between mothers and fathers.

The 1942 Civil Code was providing that 'non contractual obligations' - as typically are those emerging from illecit conducts - are to be ruled by the law of the place where the fact happened (article 25, now abrogated) and that criminal law, public and social security legislation was to be applied to anyone finding himself in the territory of the State (article 28, now abrogated). The 1995 Reform replaced such dispositions - that were essentially setting a territorial legal nexus - by specific norms on torts and non contractual liability deriving from any produced object: in such cases it is going to be applied the law of the place where the 'event' (the wrongful act with its consequences) took place, or, upon demand of who's being damaged, the law of the place where the fact happened; nevertheless, whenever the illecit conduct is regarding persons having the same nationality, then it is applicable their national law (article 62 Legge n. 218/1995). In case of damage deriving from an object, then the applicable law is the one chosen by the damaged person, who can opt for the law of the place where the producer has his domicile or his administration or the law where the product has been bought - apart from cases when the producer proves that the product was sold without his permission (article 63 Legge n. 218/1995); such a new ruling has the merit of having overcomed the uncertainty derived from the past discipline that was ignoring the difference between the 'locus commissi delicti' (the place where the crime was committed) and the place where the effects of the crime actually happened.

So the reformed private international legislation is now recognizing, much more then before, the private parties will at opting for any preferred legal system, be it on the base of a deeper knowledge of it, or be it because the material interests as involved are better dealt with by a specific legislation, while the rigid 'territorial nexus', as previously provided, is made of a more flexible application by several exceptions giving relevance to the specific circumstances and interests as involved. Italian jurisdiction is declared to be generally standing whenever the defendant has a domicile, or is resident, or has a representative being authorised to go on trial in Italy and in any other case possibly provided by the law (article 1 of Legge n.218/1995) and it can be derogated in favor of another foreign jurisdiction (or an arbitrator) whenever the parties make an express provision in writing on condition that the matter is not involving rights which cannot be renounced - as typically fundamental rights are considered to be (article 4 of Legge n. 218/1995). This is a cornerstone in social security: no genuine will could ever be accepted as such if set to renounce to, or to deny a social fundamental coverage, for social security itself having the opposite institutional purpose. 
For what is concerning contractual obligations, already in place in 1995 was the 1980 Rome Convention, which structure significantly inspired the Reform (although the former not applying to family relations and to persons' juridic capability): the 1980 Convention still affirms, as a general rule, the primacy of the parties' will to freely choose the jurisdiction and the applicable law, and, in lack of such a choice, it will be up the judge to descover the legal system having the strongest (substantial) connection to the contractual relation in dispute, eventually by considering other contracts that are linked to it. The 1980 Convention is now, for the European countries only, been replaced by EU Regulation n. 593/2008 (also known as Rome I, which, differently from the Convention, does cover matters of persons' juridic capability, except when a party can argue that his uncapability was known to the other contractor); the EU Regulation confirms, for employment contracts in particular, that "individual employment contract shall be governed by the law chosen by the parties, although such a choice may not have the result of depriving the employee of the protection afforded to him by provisions that cannot be derogated from by agreement under the law that would be applicable in absence of choice". Again the technique of inderogability is here limiting the parties's autonomous power to contract, resulting from such a norm a general limit on the parties'possibility to depart from the law of the working place whenever that would lead to deny a legal protection. The jurisdiction/law which is applicable in absence of choice is that of the country in which the employee habitually carries out his work, indeed, and such a jurisdiction cannot moreover be deemed to have changed if he temporarily is employed in another country. Whenever the applicable law cannot be determined thereby thus when it would not be clear where the worker is been habitually employed - then it will be applicable "the law of the country where the place of business through which the employee was engaged is situated" (the 1980 Rome Convention on this last point is different, insofar it refers to "the employing premise, unless all relevant circumstances are evidencing a stronger nexus with another country, which law will be the one applicable").

The public order as a general limit, meant as the duty to avoid any ruling whenever it would be leading to an evident infringement of the jurisdiction supposed to apply, stands at article 21. Such a procedural limit finds a substantial complement at article 9, refering to norms which application is 'necessary' insofar they concern widely a public interest as possibly involved in the public "political, social and economic organization". Such a formulation, whenever it comes to justification of discretional use of administrative powers dealing with social interventions in both common law and civil law, is highly explicative: it handles to public officers the biggest responsability in evidencing any possibile collision between the private settlement and the perception of the general interest.

The just mentioned EU Regulation (n. 593/2008) also expressly discipline the case of different legal system cohexisting in the same State, which fits the case of any possibly conflicting norms deriving from 'territorial units' such as different regional administrations having legislative powers: "where a State comprised several territorial units, each of which has its own rules of law in respect of contractual obligations, each territorial unit shall be considered as a country for the purposes of identifying the law applicable", nevertheless, when the conflicting laws are involving those territorial units only, the member State is not obliged under the Regulation.

The legal frameworks as just summarily reported are coherent with an international committment of the nation State to establish a social protection system based upon elementary levels of needs that can be accessible, in line with also the 1952 ILO Convention 
n. C102 on social security minimum standards. The recalled 1995 Italian Reform does not contrast with the basic concepts of such a risalent, and still in force basic ruling, willing to cover social security worldwide: therein "prescription" means determined by or in virtue of national laws or regulations, "residence" is meant as the ordinary place where the resident ordinarily stays in the territory of the member State, for "wife" is meant the wife maintened by the husband, the "widow" is the woman maintened by her husband at time of his death, for a "child" it is meant a child under school-leaving age or under 15 years of age, as may be prescribed, a "qualifing period" means a period of contribution, of employment, of residence or any combination therof, a "benefit" is both a direct benefit in the form of care or indirect benefit consisting of a reimbursment of the expences borne by the person concerned. Nevertheless, it is important to remark that member States are expressly not called to ratify the all of the Convention; for example the part recognizing medical care and unemployment is accepted by common law countries like United Kingdom, United States and Northen Ireland, but not by Italy as well, while the part regarding old age benefits and family benefits are accepted by Italy too, and maternity benefits are accepted by Italy but not by the mentioned common law states, and none of the mentioned countries have accepted, so far, the part regarding standards to be complied with periodical payments.

\section{THE EU PROPOSED DIRECTIVE ON MINIMUM/ADEQUATE WAGE}

The 2014 Italian Reform (Legge n. 183/2014), although proposing a sperimental minimum wage to be statutorily fixed on an hourly base, operating for subordinated workers and for 'coordinated workers' ('quasi subordinated' workers) insofar national collective bargaining would be not covering them, didn't itself introduce the remedy as such, while several proposals are still pending at the legislative body. Italy, together with Austria, Cyprus, Denmark, Finland, and Sweden is amongst the member States having not introduced a statutory minimum wage yet. Different proposals have been presented to the Italian Parliament for acts introducing directly a minimum salary, but none of them passed for approval so far, which indicates a tendency of the country as a one rather focused on competition, and workers competition nonetheless, to achieve better treatments. Actually what keeps granting sufficient and adequate wages in Italy still today is a collective bargaining that is finally enforced, in case of any infringement by the employer, by the judiciary; Italian hourly minimum wage, which is empirically calculated to be above the 10 euros, is told to be comparatively appreciable, while the medium level of wages is known as one greatly below the European standards.

There is an opinion according to which the labor market does not scares anymore, insofar our legal systems do provide (more or less efficiently) a protection against abuses by employers acting against single or collective dependent labor rights and even against abuses by any public administration that would deny the economic credit of a self employed worker: leaving outside the geo-political situation, "the world of labor is not scaring anymore, and, as a consequence, the post-world-war-consensus that gave basement to the (Italian) Constitution and to the organic ground from which it stamped, which was kept under sever political and cultural attack for more then fourty years, seems to be destined to lose weight" (I. MASSA PINTO). Thereafter the social conflict should be searched and defined elsewhere, where it is itself more evident, at a case-law stage, at a micro-economic dimension, wherein single and collective interests actually emerge and might be opposite the one to the others. To put it 
strictly, the social conflict stays where the social rights, not only as a direct derivation from labor, are at risk. On the European front it has been declared something slightly different, while arguing for the need of a European intervention on wages that would represent a major step ahead and a goal for the Union: "the truth is that for too many people, work no longer pays. Dumping wages destroys the dignity of work, penalises the enterpreneur who pays decent wages and distort the competition in the single market" (U. VON DER LYEN). Nor it can be forget that part of the population do not enjoy any productive nor active working activity, and the legal system, far from imposing to do so, being it for one's own sake or not, is affirming that forced labor cannot be imposed (article 5 of the European Social Charter).

The present study moved from the increasingly evident tendency, at the political level, both at public law and private international law, to link labor and social rights to a recognition before their enforcement - directly deriving from an international source, and such tendency is worthy to be focused and understood in order to avoid that any 'internationalization' becomes a short cut for reducing protections behind the illusion of a communitarian dream. The European Social Pillar, a declaration of purposes approved jointly by the European Parliament, Commission and Council during the Goteborg summit in 2017, stated at article 14 that "the one lacking of sufficient resources has the right to an adequate minimum wage granting to live with dignity in each living phase, as well as the right to an effective access to basic goods and services. For those being able to work, the minimum wage should be given together with measures to enter back in the labor market".

It must be moreover remembered the Council Recommendation on access to social protection for workers and the self employed of 8 November 2019, according to which member States are recommended to 'provide access to adequate social protection to all workers and self employed persons in effective manner and not merely formal' as well as to report about needed implementing measures to be taken at the national level by 15 November 2022, when also the Commission will be finally reporting its considerations.

The increasing interest from the EU to the social dimension of the common market does witness, on the one side, the need for a re-destribution of income amongst different subjects and areas, and, on another side, the call from national actors to transfer their social responsability to authorities that are not local, which is mainly happening in occasion of formative, training, skills-learnings goals that can be better supported by non-local actors, possibly at a lower cost and with outcomes that are considered to be more convenient from a domestic perspective.

Clear studies on the introduction of a national minimum wage tell us that such a measure could be effectively important for re-destribution of income according to the traditional perspective of a conflict between labor (wages) and capital (profits), but the same conclusion cannot be reached so easily once we consider (member) States as economic operators, because in such a case calculating the share of income going to labor and capital is becoming complicated; indeed, there must be agreement on: 1) whether or not to include/exclude public sectors employees and public corporations (are these serving a community or are they working for the general interest? 2) whether self employment is serving a merely private interest or a public one too; 3 ) how to treat rents; 4) whether the profit is to be determined pre or post tax; 5) whether the profits are best measured as a share of income or as a rate of return on capital employed. All these factors make the introduction of a minimun wage, to be 
granted by the public forces, a matter of re-destribution requiring transparency over the different public policies and private choices that are standing underneath its administration.

The debate over the proposed Directive for a European minimum wage which is currently at stake (the Commission's proposal is dated October 28th 2020), is an occasion to analyse a remedy that crosses both contributory and non contributory social legislations, and that, insofar it poses the States in a variable position of covering any lack from the involved social parties, presents itself as a tool of a highly political impact.

The European adequate wage, as formulated so far, is moreover expressly going to provide a direct European solidarity - by way of the structural European funds - to the purpose of achieving the Directive's goal; solidarity would be operating wherever not the social parties nor the States, via statues or regional regulations, would be granting the minimum wage by themselves: particularly, Consideration n. 31 of the proposed Directive sets the Technical Support Instrument and the Social European Fund Plus to possibly financing its intervention. The first of these two funds is established already, by Regulation n. 2021/240, approved last February the 10th 2021 also in express connection to the COVID-19 out break, to bring forward social integration and more generally to the purpose of implementing the Green Deal as linked to the Paris Agreement on Climate change; its scope refers to "policy areas related to cohesion, competitiveness, education, productivity, research and innovation, smart, fair, sustainable and inclusive growth, jobs and investment, with specific emphasis on actions that foster the digital and just green transitions" (also 'accessible, affordable and resilient public healthcare, social security systems, care and welfare, and childcare' are contemplated). Moreover, it is therin clarified that such technical support will be operating upon request "in order to support the implementation of reforms undertaken at the initiative of member States, reforms in the context of economic governance processes, in particular those effectively addressing the country-specific recommendations or actions related to the implementation of Union law, and reforms in relation to the implementation of economic adjustment programmes" (Consideration n. 14). As for the European Social Fund Plus, its Regulation is up to today a proposal by the Parliament and Council (FSE+) (COM (2018) 382 final.

Already from such preliminary remarks, giving the dimension of a clear economic budgetary and temporary availability from the Union, it can be argued that any further debate about the presence of a legal limitation not giving the Union itself the power to conditionate the employment national policies - as it would be emerging from article 153 co. 5 of the TFEU (a norm introduced in the Treaty before the monetary Union came into force that keeps the matter of retributions, right of association, right to strike and enterprises' right to lock-out, out from the Union policy) is expression of a conservative political position. As such, that debate is feasible to stop the achievement of the very basic goals of the European integration process, contrarily emerging from an overall understanding of the EU Treaties, starting by a fundamental norm like article 3 of the consolidated TUE, which is establishing a single market wherin social security and free movement of people is (not granted, but) pursued. Perhaps rather thicker legal obstacle for this proposal to achieve its aims is the lack of tax harmonization (article 113 TFEU), in other words, the fact that member States are still required to express unanimously for tax harmonization, a substantial matter that is primarily connected to labor transactions, might prevent from looking forward toward the increased European solidarity that is searched; maintaining such a level of member States souveranity leads more to a competition amongst member States than to a more fair distribution of the global economy results. 
The European Directive wants to achieve the goal of promoting better conditions of work (article 153, co. 1, TFEU and article 151 TFEU) by setting a framework to grant minimum and adequate remunerations, transparently and predictably, in conformity to both the national praxis and the autonomy of the social parties. Such a goal can be coherent with a system of legal minimum wage just fixed statutorily by the member States or it can be not, but nevertheless, ultimately, it sets a responsability upon the member States - to which the Directive would spread its binding vertical effects - for establishing the remedy as effectively accessible to those who are entitled. Article 11 of the Directive states strictly the duty on the States to make effective any path to claim the right: be the minimum wage granted by collective bargaining or by statute, the worker must be protected by his or her national State in the action of claiming for such right, no matter if he or her is claiming it via the judicial way or via an alternative despute resolution mechanism as that furnished by some collective agreements or by administrative bodies. The remedy must be actually available. This is putting the focus not anymore on the authority as theoretically supposed to grant the fundamental right, as a high court of justice or a trade union body might be, or also a chief office of a major enterprise in case of an internal grievance procedure, rather, the focus is put upon the substantial remedy that is needed by the physical person, or by the group of persons whose working position resulted otherwise not adequately recognized, in monetary terms, and thus not recognized to the basic purpose of social security neither. This is giving much play on member States to act back on those who are substantially responsible for not having met the Directive objective on adequate treatments.

As for determining the measure of the wage in its adequacy, the proposed act significantly remarks, far from referring to an abstract formatting parameter, which would place itself out from the labor market logics and necessities, neither referring strictly to an hourly monetization that could be easily strumentalized in relation to other valuable parameters, that the member States are required to (dynamically) update the level of (minimum) remuneration on the ground of stable and clear criteria. Particular criteria could be set, amongst which they must appear, at least : 1) effective buying power of the fixed legal wage, considered tax and social security deductions, and, on the other side 2) general level of gross wages and their distribution, growth rate of gross wages, productivity of work, as aggregate economic elements shaping the wage buying power in a dynamic perspective. Being the purpose of the Directive not that of harmonizing the labor cost in the considered area, such a result could nevertheless be on the horizon, considering the decrease of external and regional competitiveness due to the expected labor cost increase, and this is calling for a continuing monitoring of the economic trend. Expressely the proposed minimum/adequate wage could be varing for different groups of workers, and deductions will be accepted only if they are necessary, objectively determinated and proportionate (for example a reasonable deduction 'could be' provided for the use of a working tool, or a house-rent, and as coherent are kept those deductions that are emerging from a judicial provision). The social parties are plainly encouraged in promoting themselves an even better minimum treatment, the Directive is clearly affirming that any existing better treatment is not to be overcomed: any more favourable treatment, deriving from legislation, regulations and administrations, are supposed to stay, because the purpose of the act is one of rising the level of working economic and social conditions. There is going to be space for innovative regulations insofar the comparative perspective is going to be largely suggesting for any involved operators; for example it is of interest the experience of the 1983 Artist Social Insurance Act in the German context, wherin "artists and publicists have to pay their own contribution which amount- 
like in other traditional insurance schemes - to 50 percent of the overall financial sources of the insurance system and for the other half, a third is paid from the State budget (as a State subsidy) and the remaining two thirds have to be paid through a specific fee or levy which is imposed on the remunerations paid by a 'marketer' to indipendent artists and publicits in a calendar year, irrespective of whether the recipient is insured by the Artist Social Insurance Act or not" (U.BECKER \& O. CHESALINA). Also of interest might are the first attempts to rule platforms and their possible social responsability.

As for the scope of the Directive, it is going to cover "all Union's workers having an employment contract or relation as defined by law, by collective contracts or praxis in each member State, in consideration of the European Court of Justice jurisprudence"; the relevant qualification of being a "worker having an employment contract or relation", be it a legal presumption, a collective bargaining presumption or qualifcation, a presumption or a qualification as emerging by a praxis "in each member State" would be so setting the required definition, and the access to the benefit stemming from it, within the State borders. Nevertheless, also the European standards in defining who's a worker are going to be here being here relevant for any operator; the widest definition of worker given at the European level since 1968 (ECJ n. 19/68, December the 19th, De Cicco, in Racc. 1968, 627) assimilated, for previdential purposes, artisanal workers to subordinated wokers, and essentially considered the (migrant) worker as the one circulating (for whatever reason) on condition to be covered by an assurance. Contrarily to such a large personal scope, the Directive in its considerations reports that any genuine self employed does not fall under the Directive's protection, which is to much extent misleading, insofar it might prevent from claiming the right to anyone who is just qualified as a self employed, but finally, as a matter of fact, resulted a truely dependent worker after judicial acertaining, giving ex post interpretation to his working conditions (any ex post interpretation of the workers'position is based on the primacy of facts more then on formal qualification as given by the parties).

The scope of the Directive is moreover in point when it affirms that "the member States will adopt adequate measures to grant that economic operators, in executing public agreements and public concession, do conform to sectorial and geografically framed collective bargaining as well as to legal minimum wage existing". Such a formulation would be a substantial overcoming (although applicable to the public sector only) of the European jurisprudence delivered by the 2008 Ruffert and Luxemburg European Court of Justice cases, which, balancing the trade union's protective intervention and the European fundamental right to free circulation of services, produced a limiting effect on the trade unions' operations, rather favouring circulation of workers and granting them the minimum rights as established by the European Directive n.96/71 on posted workers only, not the whole collective agreement treatment as well.

Access to and financing methods of social security are told to be the two the main challenging perspectives in approaching newely to social legislation, where the financial aspect is increasingly stressed by factors like the ageing of society and digitalization. Although the proposed Directive is offering elements of clarity about minimum/adequate wage future financing from the Union, insofar it should provide a contribution by a couple of named EU funds, it must be remarked that any active demand from member States to benefit from it could be prevented from not being clear, so far, the final cost resulting on the State part rather then on the part of the Union. To some extent it might be indicative the requirement provided in the proposal for a minimum percentage of trade union coverage by 
collective bargaining - originally not below than $70 \%$ of the workers - under which an action plan by the Union would apply. So far, member States are required to mean a solidarity that must go beyond quantitative uncertainties and economic risks as normally rising from investment in human capital.

Even less clear emerging in the proposal is how accessing to such a promised remedy is going to be connected to social security basic structures: we only find the mention of possibile deductions with no clear linkage/integration to basic structures and systems of integrative social security. As a result we do have an economic remedy that would compensate the lack of a work recognition by a juridic system, but not also a remedy that collocate the concerned work in any given social security scheme, by giving it social recognition as a supplementary position nor as an integration within the basic social position for welfare. Be such an informality thought to better cover non-standard work and self employment, especially in the digital labor market, not elude the matter of how to consider social security responsability in the meanwhile: whatever is happening in the meanwhile, while contributions and deductions are imposed and subtracted, is kept unspoken.

\section{REFERENCES}

Ales Edoardo. (2015). Diritti sociali e 'discrezionalità' del legislatore nell'ordinamento multilivello: una prospettazione giuslavoristica, Relazione Congresso Associazione Italiana di Diritto del Lavoro e della Sicurezza Sociale, Foggia, 28-30 maggio

Ales Edoardo. (2021). Is the classification of work relationship still relevant issue for social security? An Italian point of view in the era of platform work, in Becker Ulrich and Chesalina Olga, Social law 4.0: challenges and opportunity in social protection, in Social Law 4.0, New approaches for ensuring and financing social security in the digital age, Studien aus dem Max-Planck-Institute fur sozialrecht und social politik, pp. 15-38

Amartya Sen. (2006). Identità e violenza, l'identità può uccidere, con trasporto, La Terza, p. 603

Becker Ulrich \& Chesalina Olga. (2021). Social law 4.0: challenges and opportunity in social protection, in Social Law 4.0, New approaches for ensuring and financing social security in the digital age, Studien aus dem Max-Planck-Institute fur sozialrecht und social politik, pp. 15-38

Bonolis Maurizio, Sabetta Lorenzo. (2019). Verso una congiunzione funzionale delle 'due etice weberiane', in Quaderni di sociologia, Nuova serie, Volume LXIII, n. 81, 3/2019

Bruno Caruso \& Loredana Zappalà. (2021). Un diritto del lavoro 'tridimensionale: valori e tecniche di fronte ai mutamenti dei luoghi di lavoro, in WP Massimo D’Antona, $\mathrm{n}$. 439/2021

Cacciari Massimo. (2020). Il lavoro dello spirito, saggio su Max Weber, Adelphi, pp.1-10

Cassese Sabino. (2021). Il diritto, i diritti, durante e oltre, l'emergenza sanitaria, Intervista di Vincenzo Poso, in Lavoro Diritti Europa, n. 2/2021

Chignola Sandro. (2012). (a cura di), Il diritto del comune, crisi della sovranità, proprietà e nuovi poteri costituenti, Ed., Uninomade, Ombrecorte

Cinelli Maurizio. (2008). Diritto della Previdenza Sociale, 2008, Giappichelli, pp. 73-112

Coase Ronald H. (2003). The problem of social cost, in Philosophy of law and legal theory, an anthology, by Dennis Patterson, Blackwell publishing, p. 407. 
European Commission. (2020). Relazione sulla Proposta di Direttiva del Parlamento Europeo e del Consiglio relativa ai salari minimi adeguati nell'Unione Europea, Bruxelles, 28.10.2020 COM (2020) 682 final 2020/0310 (COD)

Giuseppina Malerba. (2020). The winners and the loosers in the great recession era and the strategies of the European institutions, in Riv. Int. Scienze Sociali, n. 2, pp. 173-218

Massa Pinto Ilenia. (2020). Il diritto costituzionale di fronte all'emergenza Covid-19, la Costituzione in senso funzionale e la (in) consapevolezza delle tendenze autodistruttive del sistema, in Lo Stato 14/2020, p. 315

Nogler Luca. (1993). Sull'uso dell'interpretazione autentica della legge previdenziale, in Giur It. 1993, I

Paolo Giovannini. (2008). Dalla grande impresa al piccolo socialismo, in Quale economia politica per il socialismo, Il Ponte editore

Persiani Mattia. (1997). Diritto della previdenza sociale, Cedam, $9^{\wedge} E d .$, pp. 1-42

Richard A. Posner. (1981). The economics of justice, Harvard University Press

Salazar Carmela. (2015). Greed is good. L'amministrazione della giustizia in nome del popolo, Rassegna forense 3-4/2015

Yael Tamir. (2020). Why nationalism, italian translation by Marco Cupellaro, (Le ragioni del nazionalismo) Bocconi ed. 2020, p. 8 ss. p. 123 